Religare, ISSN: 19826605, v.16, n.1, agosto de 2019, p.264-281.

\title{
O Campo Religioso Brasileiro, o Estado Republicano e a implantação da Assembleia de Deus em $1911^{1}$
}

\author{
The Brazilian Religious Field, the Republican State and the \\ implantation of the Assembly of God in 1911
}

Moab César Carvalho Costa ${ }^{2}$

\begin{abstract}
Resumo
Este artigo tem como objetivo analisar o contexto socioeconômico, cultural e jurídico do Brasil no período da implantação e propagação do pentecostalismo brasileiro, a partir de 1911, principalmente o representando pelas Igrejas Evangélicas Assembleias de Deus - ADs, fundadas na cidade de Belém do Pará, pelos missionários suecos Daniel Berg e Gunnar Vingren. A efervescência econômica da cidade de Belém do Pará, proporcionado pelo ciclo da borracha associada às garantias de liberdade religiosa presentes na primeira constituição republicana de 1891 criaram condição favoráveis à sua implantação e acelerada expansão para todo o território nacional.
\end{abstract}

Palavras-Chave: Liberdade Religiosa, pentecostalismo, Assembleias de Deus, República Liberal.

\section{Abstract}

This article aims to analyze the socioeconomic, cultural and juridical context of Brazil in the period of implantation and propagation of Brazilian Pentecostalism, beginning in 1911, mainly representing the Evangelical Churches Assemblies of God - ADs, founded in the city of Belém do Pará, by the Swedish missionaries Daniel Berg and Gunnar Vingren. The economic effervescence of the city of Belém do Pará, provided by the rubber cycle associated with the guarantees of religious freedom present in the first republican constitution of 1891, created

\footnotetext{
${ }^{1}$ Este artigo é um fragmento de minha tese de doutorado em história. Aqui revisto, ampliado e corrigido.

2 Doutor em História pela UNISINOS. Professor Adjunto da Universidade Estadual da Região Tocantina do Maranhão - UEMASUL. Líder do Núcleo de Estudos Interdisciplinares em História da Religião - NEIHR. Membro da Rede Latino-Americana de Estudos Pentecostais - RELEP. Email: moabcesar@yahoo.com.br.
} 
Religare, ISSN: 19826605, v.16, n.1, agosto de 2019, p.264-281.

conditions favorable to its implantation and accelerated expansion throughout the national territory.

Keywords: Religious Freedom, Pentecostalism, Assemblies of God, Republic Liberal.

\section{Introdução}

Quando se analisa a matriz religiosa brasileira, os processos de hibridização entre as três distintas concepções religiosas que a compõe e o amálgama simbólico resultante desse processo, percebe-se que, embora plural, o campo religioso era dominado hegemonicamente pela Igreja Católica, uma vez que ela era a religião oficial até a proclamação da República e o seu braço, por muito tempo, era confundido com o do Estado. Embora existissem as instituições reguladoras do Estado em relação à religião, sendo as principais o padroado e o beneplácito, a Igreja Católica reinava absoluta e se beneficiava de sua oficialidade monopolista, impondo regras e estabelecendo leis de conduta e controle da população, sem falar nos benefícios financeiros e fiscais que gozava. Em todas essas coisas, fazia concorrência à soberania do Estado.

No período colonial brasileiro, as manifestações religiosas não católicas eram marginalizadas, proibidas e perseguidas, principalmente o judaísmo e as de origem afro e indígena. As tentativas de implantação do protestantismo de invasão foram inglórias, não em função das questões religiosas, mas, principalmente, pela questão da manutenção do território sob o poder da coroa portuguesa.

No período imperial, as manifestações religiosas relacionadas às imigrações, embora permitidas, eram insignificantes, pois deviam ser limitadas às colônias. Seus locais de cultos deveriam ser domésticos e não poderiam ser caracterizados com elementos que configurassem igrejas ou templos religiosos. 
Religare, ISSN: 19826605, v.16, n.1, agosto de 2019, p.264-281.

Essa foi uma das razões de os protestantes, e posteriormente os pentecostais no Brasil, não utilizarem o símbolo da cruz em seus templos.

O governo imperial, tendo a necessidade de atrair imigrantes - e esses, em sua maioria, protestantes - na Constituição de 1824, no artigo 5으, tirou da marginalidade a religião dos futuros imigrantes, mas limitou seu raio de ação, uma vez que trazia a seguinte disposição: “A Religião Catholica Apostolica Romana continuará a ser a Religião do Império. Todas as outras Religiões serão permitidas com seu culto doméstico, ou particular em casas para isso destinadas, sem fórma alguma exterior de Templo" (NOGUEIRA, 2012, p. 65) (Mantida a grafia original).

O advento da República modificou significativamente as possibilidades de crescimento dos protestantes e de outras denominações religiosas de cunho cristão ou da tradição judaica nas terras tupiniquins, uma vez que promoveu a laicização ou secularização do Estado, estabelecendo de forma legal a liberdade religiosa no Brasil.

No entanto, o simples fato de estar estabelecida em lei não significava, na prática, uma garantia de observação imediata, principalmente porque a nova ordem legal preconizava a mudança de estruturas simbólicas profundamente arraigadas na cultura popular e reduzia o poder das instâncias que antes detinham a hegemonia absoluta sobre a matéria. Basta, como exemplo, os cultos de origem afro, que até a década de 1980 eram perseguidos de forma violenta.

\section{As Igrejas Evangélicas Assembleias de Deus e a Liberdade Religiosa no Brasil}

Por liberdade religiosa, entendemos a não interferência do Estado nos assuntos da religião e a inexistência de uma religião oficial, que se impõe, por força de sua condição monopolista, estabelecendo limites para outros atores ou instituições religiosas (COSTA, 2017, p. 285). 
Religare, ISSN: 19826605, v.16, n.1, agosto de 2019, p.264-281.

Embora o pentecostalismo moderno tenha origem norte-americana, de onde saíram os missionários que o implantaram no Brasil, a fundação da Congregação Cristã do Brasil - CCB, em 1910, foi realizada por um italiano, enquanto a Assembleias de Deus - ADs, em 1911, foi protagonizada por dois suecos. Esses missionários não trouxeram da América a carga cultural, recheada de questões étnico-raciais, tampouco o formato institucional de suas organizações $^{3}$ e muito menos o denominacionalismo ${ }^{4}$. Eles trouxeram as marcas culturais de seus países e a determinação de estarem cumprido uma missão divina na divulgação da fé pentecostal. A chama pentecostal, essa sim, foi acesa nos Estados Unidos. Contrariando toda uma cultura racista e segregacionista, o movimento foi liderado por um americano negro e levado a muitos lugares por mulheres que, até então, não podiam nem votar. Os missionários suecos Daniel Berg e Gunnar Vingren, fundadores das ADs no Brasil, e o italiano Luigi Francescon, fundador da $\mathrm{CCB}$, movidos por ideais missionários, deram início a um movimento no Brasil que, após cem anos de sua fundação, conta com mais de 30 milhões de adeptos (IBGE, 2010).

Como conseguiram chegar a esses números? Que aspectos favoreceram seu crescimento? Numa resposta ampla e genérica, considerando os aspectos culturais do povo brasileiro, podemos conceber que isso foi possível por causa da natureza híbrida do campo religioso, da liberdade religiosa garantida por lei, da diversidade de sua matriz religiosa e da sua porosidade cultural, tendo sido

\footnotetext{
${ }^{3}$ Para Araújo (2007), do ponto de vista teológico, as ADs sofreram a influência dos dois grupos, escandinavos (suecos) e norte-americanos, respectivamente. Os escandinavos, nas primeiras cinco décadas e, os americanos, a partir da década de 1950 até os dias atuais, os quais imprimem suas marcas de forma cada vez mais visíveis, conforme registros pontuais que faremos à frente. ${ }^{4}$ Por denominacionalismo, entende-se a concepção de que todos os segmentos que professam o cristianismo, apesar de suas diferenças, pertencem a um mesmo corpo, a igreja de Cristo. Esse conceito é rejeitado por alguns segmentos, entre eles os que fazem parte do pentecostalismo clássico. As ADs no Brasil, até bem pouco tempo, negavam a possibilidade de outras denominações possuírem uma mensagem capaz de promover a salvação do indivíduo.
} 
Religare, ISSN: 19826605, v.16, n.1, agosto de 2019, p.264-281.

esses aspectos forjados dentro e sob a influência do modelo de colonização que aqui se implantou no início do século XVI.

Desde a chegada dos primeiros colonizadores portugueses, que trouxeram o catolicismo popular da Península Ibérica, a importação de africanos escravizados, com suas religiões compostas de um panteão de entidades espirituais que se manifestam no corpo dos fiéis, até a perspectiva dialógica que essas duas matrizes religiosas tiveram com o universo simbólico dos índios nativos, houve a criação e a recriação, a significação e a ressignificação dos elementos simbólicos, num processo de hibridização ${ }^{5}$ que permitiu a implantação e o crescimento dos pentecostais, de forma tímida, mas constante, nas primeiras décadas do século XX até sua explosão, a partir da década de 1980.

Outro aspecto a ser considerado é o da estrutura política e econômica do Brasil. No início do século XX, o país vivia ainda o processo de consolidação de seu sistema republicano, com uma população majoritariamente rural, mestiça e pobre. A primeira fase de crescimento foi favorecida pelos fluxos e refluxos migratórios produzidos pela economia da Borracha. A partir da década de 1950, sob influência norte-americana, dentro da política da guerra fria e do combate ao avanço do comunismo, o país iniciou o processo de industrialização, que provocou o deslocamento populacional para as cidades. No início da década de 1980, com a maioria da população vivendo nas cidades, o país passou por um

\footnotetext{
${ }^{5}$ Para Nestor Garcia Canclini (2013, p. XIX), hibridismos são processos socioculturais nos quais as estruturas ou práticas culturais, que existem de forma separada, combinam-se para gerar novas estruturas, objetos e práticas. No caso brasileiro, o catolicismo oficial não foi capaz de deter a influência de outras religiões nas práticas cristãs que aqui se sedimentaram. Também deve-se considerar que o protestantismo já estava presente desde os primórdios da colonização, quer através das invasões holandesas e francesas, quer através das imigrações (após a abertura dos portos em 1808) e, depois, através dos projetos missionários dos batistas, congregacionais, episcopais, metodistas e presbiterianos. No caso específico do pentecostalismo, com suas práticas marcadas pela presença efusiva da manifestação do Espírito Santo na glossolalia, nos cânticos, nas danças, nas curas divinas, nos cultos barulhentos e anárquicos, o amálgama simbólico aqui encontrado apresentou-se como terra fértil para sua implantação e crescimento. As práticas e crenças pentecostais encontraram manifestações similares no universo simbólico das religiões aqui estabelecidas.
} 
Religare, ISSN: 19826605, v.16, n.1, agosto de 2019, p.264-281.

processo de redemocratização política e reestruturação econômica. Esses três momentos históricos coincidem com os períodos das ondas, metáfora líquida ${ }^{6}$ utilizada por Freston (1993, p. 64-112) para elaborar uma tipologia do pentecostalismo brasileiro, ou seja, o pentecostalismo clássico ( $1^{\text {a }}$ onda - 191050), o deuteropentecoslismo ou cura divina (2 $2^{\underline{a}}$ onda $\left.-1950-80\right)$ e o neopentecostalismo (3aㅡ onda - de 1980 até os dias atuais).

Autores mais recentes como Alencar (2012), Sousa (2015) e Fajardo (2015) apresentam novas propostas de tipificação ou temporalização para o estudo do pentecostalismo brasileiro. Passos (2012) acrescentou, em suas análises, uma quarta onda às que haviam sido formuladas por Freston, sem designá-la especificamente. Essa quarta onda difere da terceira (neopentecostalismo), uma vez que empodera o indivíduo para enfrentar as dificuldades do cotidiano, promovendo o reencantamento da vida através do consumo e do sucesso na vida pessoal, além de não atribuir todas as mazelas que sobrevêm ao ser humano a Satanás e seus demônios, como faz a terceira onda. A instituição típica-ideal desse modelo, de acordo com Passos, é a Igreja Fonte da Vida, com sede nacional em Goiânia-GO, cujo público alvo é o de classe média, não da tradicional, mas, da nova classe média emergente.

Portanto, as ondas que chegaram não eliminaram as anteriores, mas dividiram espaços com elas e foram reprogramando-se, num processo de acomodação aos valores sociais vigentes em cada período, de forma que os modelos foram desenvolvendo-se em configurações sincrônicas e diacrônicas, num desenho que, com raras exceções (caso da $\mathrm{CCB}^{7}$ e da Igreja Deus é Amor),

\footnotetext{
${ }^{6}$ Zigmunt Bauman (2001, p. 8), quando retrata o estágio atual do capitalismo, também utiliza de uma metáfora líquida para demonstrar a fluidez dos tempos pós-modernos.

7 A CCB tem tentado se manter inflexível às mudanças, principalmente se comparada às que ocorreram nas ADs. No entanto, já existem indícios de que ela não conseguirá ficar imune às transformações sociais, principalmente àquelas relacionadas à valorização do indivíduo que, ao ganhar maior importância e autonomia em relação ao grupo religioso, vai questionar com maior objetividade as regras comportamentais e as relações de poder existentes dentro da instituição. Em publicação recente, Leonildo Campos apresenta algumas fissuras na CCB: “Atualmente há
} 
Religare, ISSN: 19826605, v.16, n.1, agosto de 2019, p.264-281.

delineou, por volta da década de 2010, uma unidade repleta de diversidade, mas regida por um único maestro, o sistema capitalista. Assim como as ondas do mar que surgem do mesmo caudal, retornam para ele e aguardam um novo impulso para se erguer, os pentecostalismos possuem as mesmas origens, sofreram as mesmas influências embrionárias, expandem e retornam para sua base originária, também modificada, para ganharem novos impulsos de crescimentos. Nesses casos, a mola propulsora foi a Teologia da Prosperidade, importada dos Estados Unidos, lócus de irradiação do pentecostalismo para o mundo.

Se a primeira onda chega com os missionários italianos e suecos, na segunda onda, cuja instituição de maior representatividade é a Igreja do Evangelho Quadrangular (IEQ), os missionários são norte-americanos. A terceira onda, encabeçada por brasileiros, especialmente pelo bispo Edir Macedo, fundador da Igreja Universal do Reino de Deus - IURD, vai importar a Teologia da Prosperidade e o tele-evangelismo dos Estados Unidos, hibridizando as práticas presentes na matriz religiosa brasileira e resignificando os valores adotados pela primeira e segunda onda.

É a partir da presença das igrejas que compõem a terceira onda, cujo ethos reflete os valores da sociedade capitalista vigente, que a ação proselitista se volta não apenas para os membros da Igreja Católica, mas para membros de toda e qualquer tradição religiosa. A dinâmica expansionista dessas igrejas e as técnicas proselitistas adotadas estão diretamente associadas às estratégias de marketing e mercado. Sob estas influências, o campo religioso brasileiro vai passar pelas maiores transformações de sua história, fazendo com que igrejas protestantes e pentecostais clássicas iniciem um processo de ressignificação de suas crenças e

pequenas cisões envolvendo a CCB com o aparecimento de congregações cristãs independentes. Um grupo delas forma uma rede de templos sob o nome "Congregação Cristã - Ministério de Jandira". Há também uma significativa presença de sites, alguns favoráveis e outros contra a CCB, na rede mundial de computadores" (CAMPOS, 2015, p. 232-233). 
Religare, ISSN: 19826605, v.16, n.1, agosto de 2019, p.264-281.

práticas, produzindo aquilo que é mais comum no conjunto que pode ser sintetizado como pós-modernidade: as crises de identidade.

As mudanças no ethos do pentecostalismo não é objeto desse artigo, no entanto, esse breve resumo é útil como referência para a compreensão de que as inúmeras mudanças nas ações proselitistas (evangelísticas) só foram possíveis em função de uma legislação que, em tese, garantia a plena liberdade religiosa no Brasil. É o que veremos a seguir.

\section{A República Liberal no Brasil e a Liberdade Religiosa}

A existência de um estado laico, secularizado e liberal de acordo com Mariano (2002, p. 7), é um conditio sine qua non para que as confissões religiosas estabelecidas em um determinado país possam desenvolver suas atividades proselitistas, ainda que tenha que enfrentar grupos religiosos tradicionais e mais poderosos, principalmente, como foi, no caso do Brasil, o catolicismo. Assim, e sob essas condições, o campo religioso brasileiros passou por mudanças profundas em sua estrutura a partir da década de $1890^{8}$, quando houve a

\section{${ }^{8}$ DECRETO № 119-A, DE 7 DE JANEIRO DE 1890.}

Art. $1^{\mathrm{O}} \mathrm{E}^{\prime}$ prohibido á autoridade federal, assim como á dos Estados federados, expedir leis, regulamentos, ou actos administrativos, estabelecendo alguma religião, ou vedando-a, e crear differenças entre os habitantes do paiz, ou nos serviços sustentados á custa do orçamento, por motivo de crenças, ou opiniões philosophicas ou religiosas.

Art. $2^{\mathrm{o}}$ a todas as confissões religiosas pertence por igual a faculdade de exercerem o seu culto, regerem-se segundo a sua fé e não serem contrariadas nos actos particulares ou publicos, que interessem o exercicio deste decreto.

Art. $3^{\circ} \mathrm{A}$ liberdade aqui instituida abrange não só os individuos nos actos individuaes, sinão tabem as igrejas, associações e institutos em que se acharem agremiados; cabendo a todos o pleno direito de se constituirem e viverem collectivamente, segundo o seu credo e a sua disciplina, sem intervenção do poder publico.

Art. $4^{\mathrm{o}}$ Fica extincto o padroado com todas as suas instituições, recursos e prerogativas.

Art. 5o A todas as igrejas e confissões religiosas se reconhece a personalidade juridica, para adquirirem bens e os administrarem, sob os limites postos pelas leis concernentes á propriedade de mão-morta, mantendo-se a cada uma o dominio de seus haveres actuaes, bem como dos seus edificios de culto (Mantida a grafia original). 
Religare, ISSN: 19826605, v.16, n.1, agosto de 2019, p.264-281.

separação oficial da Igreja Católica do Estado Brasileiro, propiciando as condições que tanto favoreceram a implantação e expansão do pentecostalismo.

Por outro lado, o decreto n. - 119-A do Governo Provisório, de 17 de janeiro de 1890, que abolira o padroado, estabelecera no Brasil, um regime de separação entre a Igreja e Estado que parecia uma afronta à maioria católica da população. Ela dava lugar a um estado não-confessional, em que o nome de Deus era riscado dos atos públicos, o catolicismo nivelado às seitas protestantes minoritárias no regime de liberdade religiosa (MOURA \& ALMEIDA, 2004, p. 325).

O Decreto 119-A foi ratificado pelo Art. 72 da primeira constituição republicana, promulgada em 24 de fevereiro de $1891^{9}$ e pelas emendas constitucionais de 3 de setembro de 1926 que, além de manter a garantia à liberdade religiosa para brasileiros e estrangeiros $\left(\S 3^{\circ}\right)$, passou a reconhecer

9 Art. 72 - A Constituição assegura a brasileiros e a estrangeiros residentes no paiz a inviolabilidade dos direitos concernentes á liberdade, á segurança individual e á propriedade, nos termos seguintes: (Redação dada pela Emenda Constitucional de 3 de setembro de 1926)

$\S 1^{\circ}$ Ninguém pode ser obrigado a fazer, ou deixar fazer alguma cousa, senão em virtude de lei. (Redação dada pela Emenda Constitucional de 3 de setembro de 1926)

$\S 2^{o}$ Todos são iguaes perante a lei. (Redação dada pela Emenda Constitucional de 3 de setembro de 1926) [...]

$\S 3^{\mathrm{o}}$ Todos os indivíduos e confissões religiosas podem exercer publica e livremente o seu culto, associando-se para esse fim e adquirindo bens, observadas as disposições do direito commum. (Redação dada pela Emenda Constitucional de 3 de setembro de 1926)

$\S 4^{\circ}$ A República só reconhece o casamento civil, cuja celebração será gratuita. (Redação dada pela Emenda Constitucional de 3 de setembro de 1926)

$\S 5^{\circ}$ Os cemiterios terão caracter secular e serão administrados pela autoridade municipal, ficando livre a todos os cultos religiosos a prática dos respectivos ritos em relação aos seus crentes, desde que não offendam a moral publica e as leis. (Redação dada pela Emenda Constitucional de 3 de setembro de 1926)

$\S 6^{\circ}$ Será leigo o ensino ministrado nos estabelecimentos públicos. (Redação dada pela Emenda Constitucional de 3 de setembro de 1926)

$\S 7^{\circ}$ Nenhum culto ou igreja gosará de subvenção official, nem terá relações de dependencia ou alliança com o Governo da União, ou o dos Estados. A representação diplomatica do Brasil junto á Santa Sé não implica violação deste princípio. (Redação dada pela Emenda Constitucional de 3 de setembro de 1926) (CONSTITUIÇÃO DE 1891. Disponível em: http://www.planalto.gov.br/ccivil_03/Constituicao/Constituicao91.htm) (Mantida a grafia original). 
Religare, ISSN: 19826605, v.16, n.1, agosto de 2019, p.264-281.

apenas o casamento civil $\left(\S 4^{\stackrel{0}{ })}\right.$. Os cemitérios passaram a ter caráter secular e com liberdade de celebração de rituais fúnebres para todas as formas religiosas $\left(\S 5^{\circ}\right)$. Foi criado o ensino leigo nos estabelecimentos públicos $\left(\S 6^{\circ}\right)$. As garantias foram mantidas nas constituições subsequentes, mesmo na de 1937, outorgada pela ditadura do Estado Novo e na "promulgada" em 1967, pela ditadura militar.

Outro fato associado ao processo de construção do Estado laico, de acordo com Mariano (2002, p. 15), foi aquele que, em consequência da liberdade religiosa, engendrou o pluralismo e um vasto e concorrente mercado religioso, que atraiu e estimulou, por causa da diversidade de ofertas, indivíduos dos mais diferentes segmentos da sociedade. Tese que contrariou a perspectiva de Berger (1985), que via na pluralização religiosa um elemento de secularização tanto da esfera pública (Estado) quanto da esfera individual, pois afirmava que na diversidade de ofertas haveria a relativização das crenças e o enfraquecimento das estruturas de plausibilidade, que gerariam o ceticismo e a descrença. Para Mariano (2002, p. 3), quanto maior a diversidade de ofertas religiosas, para os mais diferentes perfis sociais, maior seria a mobilização e participação da população nas atividades religiosas.

Assim, uma sociedade secularizada, que garante a liberdade religiosa é, por consequência, marcada pelo pluralismo religioso. No pluralismo religioso, as variedades de ofertas aumentam as opções que os indivíduos podem fazer para atender suas necessidades. Em decorrência, o trânsito religioso é intensificado, até mesmo exacerbado, aumentando significativamente a concorrência no campo religioso, formando, um mercado religioso; não só um mercado, mas, um livremercado, com uma variedade imensa de produtos e serviços que objetivam atender às necessidades mais imediatas e, até mesmo, as promessas futuras, que antes ocupavam um lugar de destaque nos cardápios religiosos e que só poderão ser adquiridas no além, como é o caso da vida após a morte. 
Religare, ISSN: 19826605, v.16, n.1, agosto de 2019, p.264-281.

Nesse sentido, o que alavanca o processo é a diversidade das ofertas - que buscam atrair uma clientela que se torna cada vez mais autônoma e, por consequência, mais exigente, tendo como preferência aquelas que melhor atendem suas necessidades - e não a demanda.

A secularização do Estado por meio do estabelecimento legal da liberdade religiosa, além de promover uma maior autonomização dos sujeitos em relação aos interesses das instituições religiosas, promoveu uma maior soberania do Estado em relação a outras instancias que dividiam o poder como ele.

Vejamos, ao estabelecer de forma legal a liberdade religiosa no Brasil, o Estado não estava nada preocupado com as minorias religiosas e suas condições marginais numa sociedade marcada pela supremacia de uma instituição religiosa. Objetivava, antes de qualquer outra coisa, estabelecer e ampliar sua soberania sobre a sociedade, eliminar toda e qualquer forma de concorrência ao seu aparato jurídico, podendo, a partir de então, elaborar e impor leis e mecanismos eficazes para garantir seu controle em todas as esferas da sociedade, inclusive da religiosa, pois será ele o responsável por fazer cumprir o direito à liberdade religiosa, bem como garantir a punição daqueles que não respeitem essa condição.

No caso brasileiro, o pentecostalismo se valeu, em várias ocasiões, dessa prerrogativa para desenvolver suas atividades evangelísticas, pois, no diários dos pioneiros das ADs no Brasil encontramos várias referências sobre a tranquilidade que gozavam os missionários suecos em propagar o pentecostalismo e, mesmo que fossem alvos de denúncias e tivessem que comparecer diante das autoridades, nada lhes acontecia, pois tinham consciência dessa garantia constitucional ${ }^{10}$ e para ela apelavam com sucesso todas as vezes que era necessário (VINGREN, 1987, p. 120).

\footnotetext{
${ }^{10}$ Apesar das garantias constitucionais, os missionários sofriam perseguições por parte da Igreja Católica. O Missionário Samuel Nyström faz o seguinte relato: “Ao chegarmos numa pequena vila de nome Boa Vista, fui levado pela polícia, que pensou ser eu um espião alemão. Mas todos
} 
Religare, ISSN: 19826605, v.16, n.1, agosto de 2019, p.264-281.

Não só as novas estruturas jurídicas favoreceram o crescimento do pentecostalismo na sua fundação, como também as novas possibilidades econômicas, fruto das transformações geradas pela substituição da mão-de-obra escrava pela livre, pelo advento da República liberal, pela euforia econômica produzida pela cultura do café (no Sudeste) e a extração borracha (no Norte) entre a segunda metade do século XIX e o primeiro decênio do século XX.

A implantação de uma república liberal impunha, também, a adoção de uma nova ordem econômica e uma reestruturação das cidades, pautadas pelo progresso propagado pelas ondas de modernização aos moldes europeus, com políticas de reordenamento urbano, projetos sanitários profundos, mudanças nos hábitos sociais e aburguesamento das novas elites. $\mathrm{O}$ país estava aberto para novas experiências. Não apenas as cidades de São Paulo e do Rio de Janeiro passaram por esses processos, mas também, cidades como Belém do Pará e Manaus, no Amazonas, tiveram seus momentos de explosão econômica, urbana e social, atraindo pessoas de várias partes do mundo, sendo transformadas em cidades cosmopolitas e pululantes.

Porém, nem tudo era tão belo assim, pois o projeto modernizador ampliava cada vez mais as desigualdades. Nas grandes cidades, as concepções sanitaristas aliadas as de reordenamento urbano alijaram para as periferias negros e pobres, dando origem às favelas, guetos de indesejáveis ou depósitos de mão-de-obra barata.

Os anos posteriores à proclamação da República foram marcados por um turbilhão de mudanças. A europeização, antes restrita ao ambiente doméstico, transforma-se agora em objetivo - melhor seria dizer "obsessão" - de políticas públicas. Tal qual na maior parte do mundo ocidental, cidades, prisões, escolas e hospitais

do barco sabiam quem eu era. Esta desculpa era comum neste tempo de guerra, tanto missionários como evangelistas eram acusados de espião. Até irmãos brasileiros eram acusados pelos padres de serem espiões quando testificavam de Jesus. Quando a polícia viu os meus documentos e as recomendações da polícia de Belém, pediu desculpas pelo que tinha feito" (NYSTRÖM, 1987, p. 33). 
Religare, ISSN: 19826605, v.16, n.1, agosto de 2019, p.264-281.

brasileiros passam por um processo de mudança radical, em nome de controle e aplicações de métodos científicos [...]. Por apresentar uma visão otimista do presente e do futuro, o final do século XIX e início do XX foram caracterizados - seguindo a moda europeia - como sendo uma belle époque. Havia, contudo, uma face sombria nesse período. O início da República conviveu com crises econômicas, marcadas por inflação, desemprego e superprodução de café. Tal situação, aliada à concentração de terras e à ausência de um sistema escolar abrangente, fez que maioria dos escravos recém-libertos passasse a viver um estado de quase completo abandono. Além dos sofrimentos da pobreza, tiveram de enfrentar uma série de preconceitos cristalizados em instituições e leis, feitas para estigmatizá-los como subcidadãos, elementos sem direito a voz na sociedade brasileira (PRIORE \& VENÂNCIO, 2010, p. 219-220).

De acordo com Sarges (2010, p. 130), a cidade de Belém do Pará, lócus irradiador do pentecostalismo das ADs no Brasil, entre os anos de 1870 e 1910 viveu a ilusão de ser um pedacinho da Europa no Brasil, período conhecido como belle époque. A borracha mudou a face da cidade, interligou a região Norte do Brasil com o modelo do que seria "um mundo civilizado" (leia-se, Europa), criou grandes fossos de desigualdades sociais e, como é comum em toda economia dependente do mercado externo, entrou em colapso diante da concorrência externa asiática. Com a mesma elasticidade que recebeu milhares de migrantes, vindos principalmente da Região Nordeste, a partir de seu descenso econômico no início da década de 1910, estilingou-os de volta, espalhando-os para várias regiões do Brasil.

A migração e a urbanização são consideradas, pela maioria absoluta dos estudiosos do pentecostalismo brasileiro, como conditio sine qua non para o seu êxito e crescimento acelerado. No primeiro momento, esses elementos criaram um fluxo de migrantes nordestinos para a região Norte, bem como um refluxo dos mesmos de volta para a terra natal e para outras regiões do país que lhes fossem mais favoráveis economicamente. Essa movimentação populacional permitiu que as crenças pentecostais se espalhassem rapidamente nas três décadas posteriores à fundação das ADs, primeiro para o Nordeste, depois para 
Religare, ISSN: 19826605, v.16, n.1, agosto de 2019, p.264-281.

as regiões Sudeste e Sul do País. Nesse sentido, muitos migrantes que passaram pela conversão ao pentecostalismo na cidade de Belém do Pará levaram consigo um elemento que as políticas econômicas, sanitaristas e racistas da belle époque não poderiam lhes expropriar: um novo estilo de vida e uma nova concepção de mundo, um novo ethos, pautado numa perspectiva resignada de que todo o sofrimento do presente momento se tornaria em recompensa em uma vida no Além e que essa concepção deveria ser propagada, primeiro para seus familiares e, de forma concomitante, para todos os homens. Tanto é, que as ADs foram criadas nos diversos estados a partir de um pequeno núcleo já existente - uma família ou duas no máximo - de pessoas que haviam recebido a mensagem através de parentes que passaram pela experiência pentecostal em Belém do Pará, no fluxo e refluxo das migrações.

A urbanização, que se acentuou a partir da década de 1950, foi responsável pelo desencaixe cultural do migrante, produzindo anomia, uma vez que substituiu as formas tradicionais que estruturavam o mundo rural (GIDDENS, 1991, p. 31-40). Nesse sentido, as ADs proporcionaram a inclusão desses indivíduos em seu seio, restaurando o sentido de comunidade primária, perdido no desencaixe do tempo e espaço e, por consequência, a nomia social ou, no mínimo, uma sensação de pertença que a partir de então passariam a engendrar uma nova identidade: o crente das Assembleias de Deus.

E, em consequência, o crescimento das ADs no Brasil, diferente do que aconteceu nas ADs do Estados Unidos (igrejas de brancos e ricos, marcadas pela segregação racial), encontrou solo fértil entre os mais pobres: migrantes nordestinos fugindo da seca, seringalistas, ex-escravos, sertanejos e deserdados sociais, ou seja, pelos que traziam as marcas da síndrome marginal.

Por outro lado, a CCB canalizava seus esforços nas colônias italianas em São Paulo. Essa postura da CCB foi responsável por seu crescimento rápido nas duas primeiras décadas de sua fundação e também por seu retraimento posterior, 
Religare, ISSN: 19826605, v.16, n.1, agosto de 2019, p.264-281.

sendo ultrapassada pelas ADs, que avançaram rapidamente no campo religioso devido a sua ação pulverizada e focada em segmentos mais vulneráveis da sociedade.

De acordo com Rolim:

Enquanto a Congregação Cristã buscava em São Paulo seu enraizamento através principalmente de italianos, a Assembléia de Deus ia pontilhando o Norte, carregada pelas camadas pobres da população brasileira. Estas faixas pobres, com muito escassas possibilidades de melhoria de vida e com praticamente nenhuma participação nos cultos católicos oficiais, encontraram nas celebrações deste ramo pentecostal momentos propiciadores da espontaneidade e liberdade religiosas. No limiar da segunda década do século, o pobre começava a ter vez, numa presença ativa, em templos que ele mesmo ajudou a construir e que os considera como seus. Além disso, a forte tendência à glossolalia, e as orações coletivas, que a Assembléia veio destacar, respondiam desde o início às aspirações religiosas dos pobres (ROLIM, 1985, p. 42).

No contexto da consolidação do movimento republicano brasileiro, com verve liberal, secularizada e focada no desenvolvimento das cidades, o pentecostalismo se desenvolveu, criou raízes, impõe hábitos e fragmentou o campo religioso brasileiro. Ainda que a liberdade religiosa fosse plena apenas na letra da lei.

\section{Considerações Finais}

As limitações espaciais deste texto nos conduziram a uma análise limitada das consequências da implantação de uma república liberal no Brasil e dos efeitos da liberdade religiosa estabelecida. É certo que para os segmentos do cristianismo aqui estabelecidos os efeitos da lei de liberdade foram sentidos, em maior ou menor grau, e ampliados à medida que o tempo passava. Tornou-se uma aliada poderosa. Por outro lado, as tradições não cristãs, principalmente as 
Religare, ISSN: 19826605, v.16, n.1, agosto de 2019, p.264-281.

de matriz africana, em tese contemplados pela lei, ficaram de fora, à margem de seus efeitos, sendo discriminadas e perseguidas.

Passados mais de um século de seu estabelecimento, a percepção de uma liberdade religiosa plena no Brasil ainda não é uma certeza, principalmente para as de tradição não cristãs, como pôde ser percebida na pesquisa realizada pelo antropólogo Ari Pedro Oro (2012). Oro realizou pesquisa de campo na cidade de Porto Alegre, em 2009, com o objetivo de perceber o olhar interno dos que se declaram adeptos das principais tradições religiosas presentes no Brasil. Distribuiu a amostra de acordo com os percentuais de cada segmento, perguntando se eles concordavam com a seguinte afirmação: “No Brasil existe total liberdade religiosa". De acordo com o autor, do total de 384 indivíduos abordados, " $49 \%$ dos entrevistados concordam plenamente com a afirmação e $24 \%$ em parte. Discordaram totalmente $7 \%$ dos entrevistados e discordaram em parte $14 \%$, totalizando $21 \% "$ (ORO, 2012, p. 182).

Os dados da pesquisa revelaram ainda que os adeptos das religiões afrobrasileiras, os das "novas religiões" e os "sem religiões" foram os que mais fizeram ressalvas sobre a existência de uma plena liberdade religiosa no Brasil. Em decorrência desses posicionamentos, concluiu que tais posturas decorrem da percepção de que suas preferências religiosas não desfrutam do mesmo grau de status social como ocorre entre os cristãos, tanto do catolicismo quanto das igrejas protestantes e pentecostais (ORO, 2012, p. 193).

Esse constrangimento em função da opção religiosa também pode ser percebido na declaração que adeptos das religiões da matriz africana fazem aos pesquisadores do Censo do IBGE. Em 2017 orientamos um TCC no curso de História da Universidade Estadual da Região Tocantina do Maranhão UEMASUL, sobre o sincretismo religioso na cidade de Imperatriz-MA, com foco na Umbanda e no Catolicismo. No censo de 2010 consta que na cidade de Imperatriz-MA apenas 22 pessoas se declararam adeptas da Umbanda. Quando 
Religare, ISSN: 19826605, v.16, n.1, agosto de 2019, p.264-281.

realizamos o trabalho de campo, com o objetivo de fazer uma cartografia das tendas de Umbanda na cidade, foi possível cadastrar 14 tendas ou centros de Umbanda e um de Candomblé (SILVA; COSTA, 2017, p. 20-27).

Essa disparidade entres os dados do Censo do IBGE e a percepção do campo empírico revelam o grau de constrangimento social dos adeptos dessas tradições. Nesse caso, a dupla filiação religiosa é sempre omitida, e a opção pelo catolicismo é menos embaraçoso, revelando o quão constrangedor é, no Brasil, se declarar adepto ou simpatizante de uma tradição não cristã.

\section{Referências}

ALENCAR, Gedeon Freire. Assembleias Brasileiras de Deus: teorização, história e tipologia - 1911- 2011. Tese (Doutorado em Ciências da Religião), São Paulo: Pontifícia Universidade Católica de São Paulo, 2012.

ARAÚJO, Isael. Dicionário do Movimento Pentecostal, Rio de Janeiro, CPAD, 2007. BAUMAN, Zigmunt. Modernidade líquida. Tradução de Plínio Dentzien. Rio de Janeiro: Zahar, 2001.

BERGER. Peter. O dossel sagrado: elementos para uma teoria sociológica da religião. Tradução de José Carlos Barcelos. São Paulo: Paulus, 1985.

CAMPOS, Leonido. Posfácio: o protestantismo brasileiro e a "iluminação interior" na perspectiva de Émile Léonard. In: LÉONARD, Émile. O iluminismo num protestantismo de constituição recente. Brasília: Monogenismo, 2015.

CONSTITUIÇÃO BRASILEIRA DE 1891. Disponível em: http://www.planalto.gov.br/ccivil_03/Constituicao/Constituicao91.htm . Acesso em 29/03/2016.

COSTA, Moab César Carvalho. O aggiornamento do pentecostalismo: as Assembleias de Deus no Brasil e na cidade de Imperatriz-MA (1980 - 2010). Tese (Doutorado em História) São Leopoldo, 2017.

FAJARDO, Maxwell Pinheiro. "Onde a luta se travar": a expansão das Assembleias de Deus no Brasil Urbano (1946-1980). Tese (Doutorado em História). São Paulo: Universidade Estadual Paulista - UNESP, 2015.

FRESTON, Paul. Protestantes e política no Brasil: da Constituinte ao Impeachment. Tese (Doutorando em Ciências Sociais). Campinas: Universidade de Campinas, 1993.

GIDDENS, Anthony. As consequências da modernidade. Tradução de Raul Fiker. São Paulo: Unesp, 1991. 
Religare, ISSN: 19826605, v.16, n.1, agosto de 2019, p.264-281.

IBGE. Censo Demográfico 2010. Base de dados disponível em: $<$ www.ibge.gov.br>.

MARIANO, Ricardo. Secularização do Estado, liberdades e pluralismo religioso. Em: www.naya.org.ar/congreso2002/ponencias/ricardo_mariano.htm. Acesso em: 28/03/2015.

MOURA, Sergio Lobo de, ALMEIDA. José Maria Gouvêa de. A Igreja na Primeira República. In FAUSTO. Boris (Org.) O Brasil Republicano: sociedade e instituições (1889-1930). Rio de Janeiro: Bertrand Brasil, 2004, p. 321-342.

NOGUEIRA, Octaciano. Constituições Brasileiras: 1824. Brasília: Senado Federal Secretaria de Edições Técnicas, 2012, v. 1.

NYSTRON, Samuel. Trabalho de evangelização no Norte do Brasil. In: ONGMAN, Paul. Despertamento apostólico no Brasil. Tradução de Ivar Vingren, Rio de Janeiro: CPAD, 1987, p. 23-43.

ORO, Ari Pedro. Liberdade religiosa no Brasil: as percepções dos atores sociais. In: ORO, A. P. et all (Orgs.). A religião no espaço público: atores e objetos. São Paulo: Terceiro Nome, 2012, p. 181-193

PASSOS, Paulo Rogério Rodrigues. Igreja Neopentecostal Fonte da Vida: a restauração da individualidade como estratégia de conversão e empoderamento da classe média brasileira. (Tese de Doutorado em Ciências da Religião). Goiânia: PUC de Goiás, 2012.

PRIORI, Mary Del, VENÂNCIO, Renato. Uma breve história do Brasil. São Paulo: Planeta, 2010.

ROLIM. Francisco Cartaxo. Pentecostais no Brasil: Uma interpretação sócioreligosa. Petrópolis: Vozes, 1985.

SARGES, Maria de Nazaré. Belém: riquezas produzindo a Belle-Époque. Belém: Paka-Tatu, 2000.

SILVA, Andreza de Sousa. COSTA, Rejane Sousa. Sincretismo Religioso na Cidade de Imperatriz-MA: entre a umbanda e o catolicismo. Monografia (Licenciatura em História), UEMASUL, 2017.

SOUSA, Bertone Oliveira. O pentecostalismo na história brasileira: problemas de periodização e enforques teórico-metodológicos. RBHR-ANPUR, ano VIII, n. 22. 2015, p. 25-38.

VINGREN, Ivar. Gunnar Vingren, o diário do pioneiro. Rio de Janeiro, CPAD, 1987.

Recebido em 21/06/2018.

Aprovado em 15/07/2019. 